\title{
Advanced, Low/Zero Emission Boiler Design and Operation
}

\section{Quarterly Technical Progress Report}

Reporting Period from April 1 1, 2004 through June 30, 2004

Submitted by:

Fabienne Châtel-Pélage and Rajani Varagani

American Air Liquide, Chicago Research Center

5230 S. East Avenue

COUNTRYSIDE, IL 60525

Issued in July 2004

Work Performed Under Contract No.: DE-FC26-02NT41586

Submitted to:

NETL ADD Document Control BLDG. 921

U.S. Department of Energy

National Energy Technology Laboratory

P.O. BOX 10940

Pittsburgh, PA 15236-0940

Subcontractors who participated in the production of the report:

Babcock and Wilcox Research Center,

Hamid Farzan

1562 Beeson Street,

P.O. Box 835,

Alliance OH 44601-2196

Illinois State Geological Survey

Yongqi Lu, Massoud Rostam-Abadi and Scott Chen

615 East Peabody Drive

Champaign IL 61820 


\section{DISCLAIMER}

This report was prepared as an account of work sponsored by an agency of the United States Government. Neither the United States Government nor any agency thereof nor any of their employees, makes any warranty, express or implied, or assumes any legal liability or responsibility for the accuracy, completeness, or usefulness of any information, apparatus, product, or process disclosed, or represents that its use would not infringe privately owned rights. Reference herein to any specific commercial product, process, or service by trade name, trademark, manufacturer, or otherwise does not necessarily constitute or imply its endorsement, recommendation, or favoring by the United States Government or any agency thereof. The views and opinions of authors expressed herein do not necessarily state or reflect those of the United States Government or any agency thereof. 


\section{ABSTRACT}

This document reviews the work performed during the quarter April - June 2004. Task 1 (Site Preparation) had been completed 2003, along with three weeks of oxycombustion tests in Task 2 (experimental test performance) of the project. In current reporting period, the experimental testing has been completed: one additional week of tests has been performed to finalize the optimization of the combustion characteristics in $\mathrm{O}_{2} / \mathrm{CO}_{2}$ environment ; two more days of testing were dedicated to mercury sampling in air-fired or $\mathrm{O}_{2}$-fired conditions, and to characterization of heat transfer in $\mathrm{O}_{2}$ conditions vs to air-blown conditions. Task 3 (TechnoEconomic Study) has also been completed in current quarter: 250MWe, 500MWe and 1000MWe oxygen-fired PC unit have been simulated and quoted, and their performance and cost have been compared to same-capacity air-fired pulverized coal (PC) unit and IGCC. New and retrofit cases have been evaluated. The comparison has been completed in terms of capital cost, operating cost, cost of electricity and cost of $\mathrm{CO}_{2}$ avoided. The scope of task 4 (Conceptual Boiler Design) had been modified as per DOE request in previous quarter. Engineering calculations are currently in progress. Next steps include detail review of the experimental data collected during the entire testing campaign, finalization of detailed report on economic task, and reporting of the preliminary results in the boiler design task. Two papers summarizing the project main achievements have been presented at Clearwater coal conference in April 2004 (overall project results), and at the $\mathrm{CO}_{2}$ sequestration conference in May 2004 (emphasis on economics). Out of the $\sim \$ 785 \mathrm{k}$ allocated DOE funds in this project, $\$ 545 \mathrm{k}$ have been spent to date, mainly in site preparation, test performance and economics assessment. In addition to DOE allocated funds, to date approximately $\$ 400 \mathrm{k}$ have been cost-shared by the participants, bringing the total project cost up to \$945k as on June 30, 2004. 


\section{TABLE OF CONTENTS}

DISCLAIMER

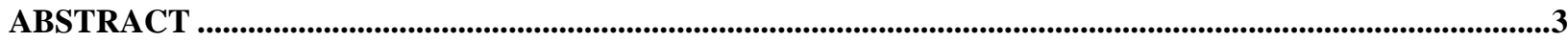

TABLE OF CONTENTS …….......................................................................................................................4

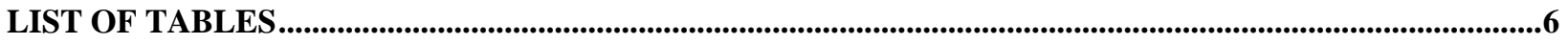

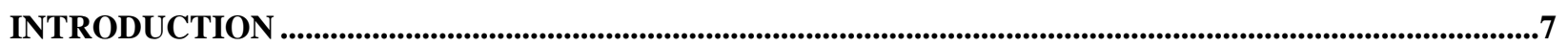

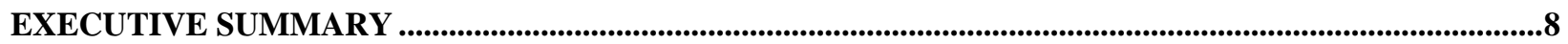

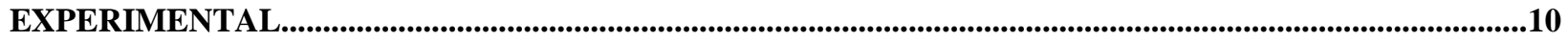

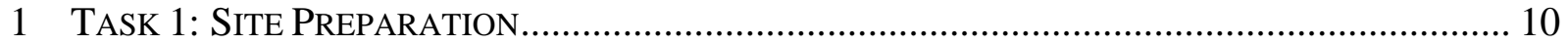

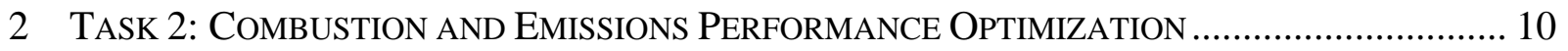

2.1 Summary of conclusions from previous reporting periods ...............................................................10

2.2 Tests performed during the reporting period ....................................................................................................11

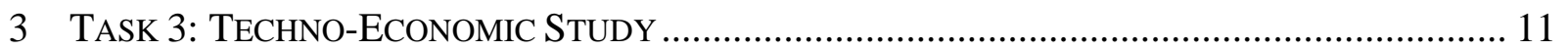

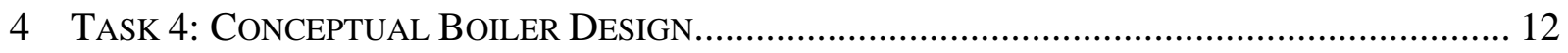

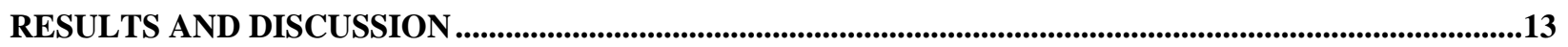

1 TASK 2: COMBUSTION AND EMISSIONS PERFORMANCE OPTIMIZATION ............................... 13

1.1 Switching procedure from air-fired to oxygen-fired operation ..........................................................13

1.2 Overall Combustion characteristics in $\mathrm{O}_{2} / \mathrm{CO}_{2}$ environment - burner stoichiometry .............................13

1.3 Emmissivity Measurement.......................................................................................................................14

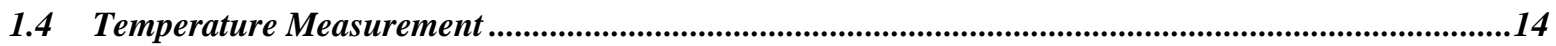

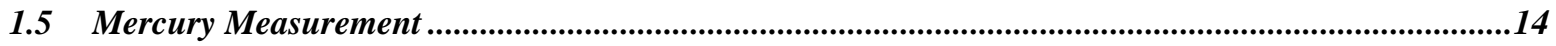

2 TASK 3: TECHNO-ECONOMIC STUDY ...................................................................... 14

2.1 AIR BLOWN PC BOILER CASES WITH AND WITHOUT $\mathrm{CO}_{2}$ REMOVAL...................................14

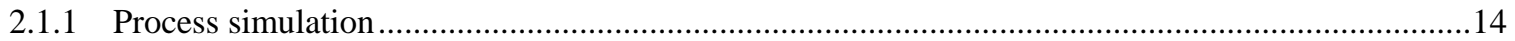

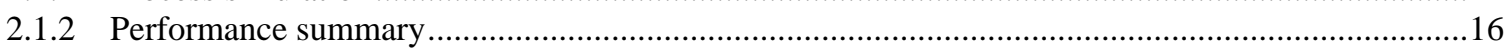

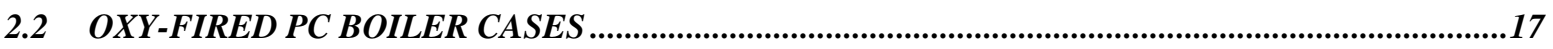

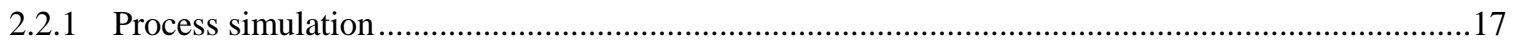

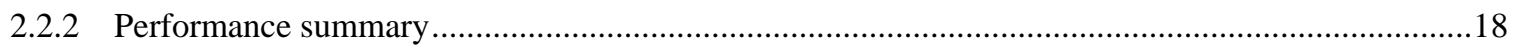

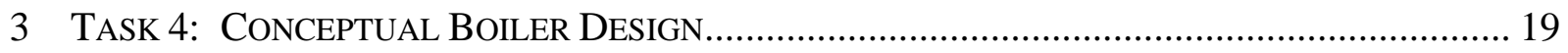

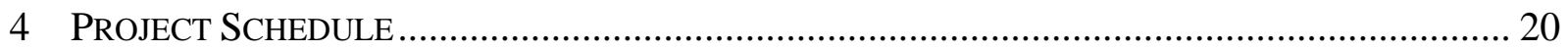

4.1 Status of the project tasks and sub-tasks.......................................................................................................20

4.2 Next quarters sub-tasks ..........................................................................................................................21

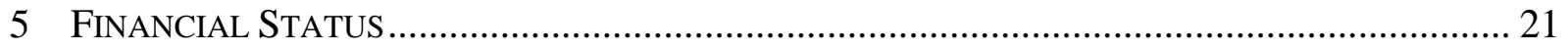

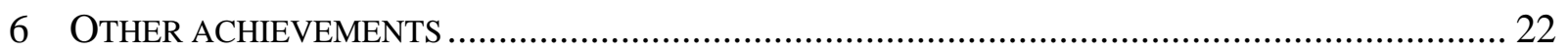

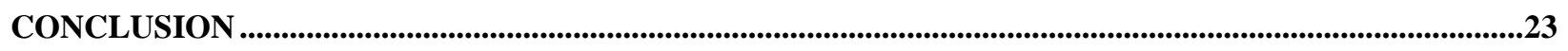

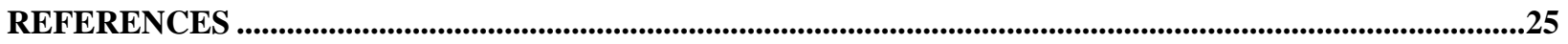

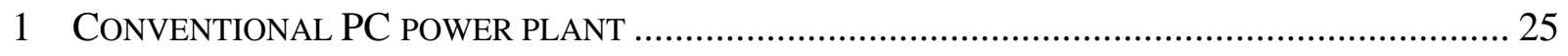

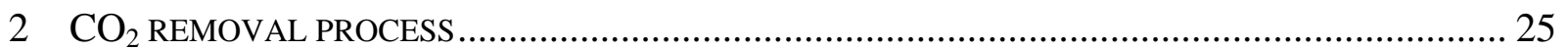

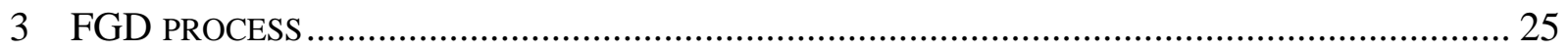

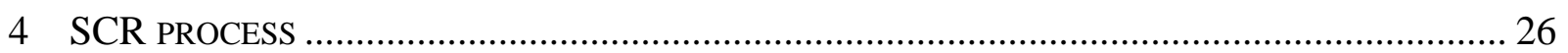




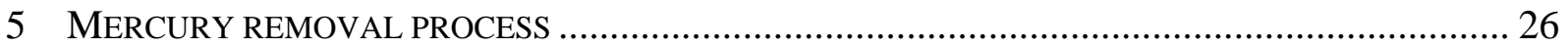

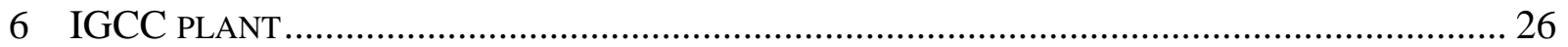

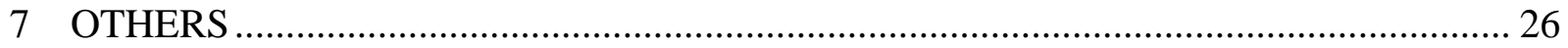

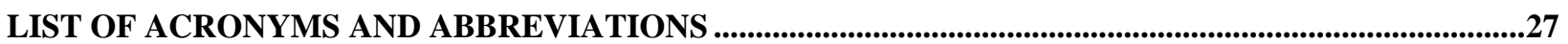




\section{LIST OF TABLES}

Table 1: Scenarios for techno-economic analysis.................................................................. 12

Table 2: Main operating parameters of the air-blown PC plants .............................................. 15

Table 3. Auxiliary power use in the air-blown PC plants with and without $\mathrm{CO}_{2}$ capture ............ 16

Table 4. Overall process performances of air-blown PC plants ............................................... 16

Table 5. Main operating parameters of the OEC processes (99\% purity O2 used).................... 17

Table 6. Auxiliary power usage in the oxy-combustion processes ............................................ 18

Table 7. Overall process performances of the OEC plants ...................................................... 19

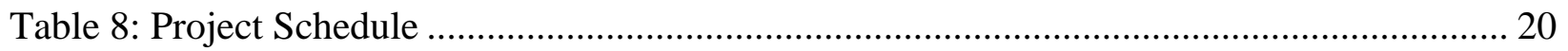

Table 9: Financial situation to-date................................................................................ 21

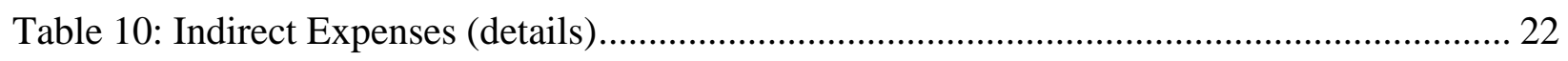




\section{INTRODUCTION}

The present report summarizes the work performed by the participants from April $1^{\text {st }}$, 2004 through June 30, 2004 (Q2 2004, Q7 of the project).

In the previous quarters (Q1, Q2, Q3 \& Q4 2003: the first budget period and Q1 2004), the site preparation (Task 1) of the experimental test campaign had been completed and the final configuration of the pilot boiler had been described. The main part of the test performance task (Task 2: "Combustion and Emission Performance Optimization") had also been completed, demonstrating the feasibility and characterizing the performance of the oxycombustion process in a $1.5 \mathrm{MW}_{\text {th }}$ boiler. Two-third of the Techno-Economic Study (Task 3) had also been performed. A detailed description of the methodology to be applied had been provided, along with basic references and overall selection of plant capacity and equipment to be evaluated. Process simulation and cost assessment of 500MWe air-fired and oxygen-fired pulverized coal (PC) units had been performed, and the comparison has been extended to two IGCC units. Task 4 (Conceptual Boiler Design) had also been initiated.

In the current quarter (Q2, 2004), the tests scheduled in task 2 have been completed. Preliminary results are provided in the "Results and Discussion section". Detailed analysis is in progress. Task 3 has also been completed, and the final report of this task is under preparation. Engineering calculations are in progress in task 4.

This report also provides an update of the project financial status and schedule. 


\section{EXECUTIVE SUMMARY}

The main effort of this quarter (April - June 2004) was primarily dedicated to Task 2 (Test performance) \& Task 3 (Techno-Economic Study) of the project. The main achievements resulting from current reporting period are the following:

Task 1 (Site Preparation), had been completed in Q3 2003, and the final boiler configuration, as available for testing, had been described.

Task 2 (Tests performance) has been completed. In addition to data collected in 2003 on oxy-fired boiler and on air-fired boiler, the heat transfer characteristics and mercury samples have been collected. Although these results are yet to be fully analyzed and discussed, the highlights are as follows:

- Burner stoichiometry, Flame stability and NO x emission: to avoid getting a cooler and less stable flame in $\mathrm{O}_{2} / \mathrm{CO}_{2}$ conditions vs air-conditions, a same burner has to be operated at higher burner stoichiometry in oxy-configuration. This is due to higher molecular weight and heat capacity of $\mathrm{CO}_{2}$ vs $\mathrm{N}_{2}$. Increasing the burner stoichiometry in oxy-combustion is feasible without affecting $\mathrm{NO}_{\mathrm{x}}$ levels thanks to flue gas recirculation which keeps the $\mathrm{NO}_{\mathrm{x}}$ emission very low $\left(<0.1 \mathrm{lb} / 10^{6} \mathrm{Btu}\right)$ through the reburn mechanism.

- Emmissivity Measurement: The measured emissivity indicated that the flame emissivity under the oxy-combustion is similar to the flame emissivity under normal air firing conditions.

- Temperature Measurement: Gas Temperature (GT) measurements were performed at the flame (FGT), furnace exit (FEGT), and the convection pass (CPEGT) outlet for both air firing and oxy-firing, while the overall mass flow rate was kept constant. The data are being analyzed. Pilot results seem to indicate that under those optimized conditions, the temperature profiles are similar in oxy-firing and in air-firing conditions (previous tests showed an average FEGT $70^{\circ} \mathrm{F}$ lower in oxy-firing).

- Mercury Measurement: Mercury sampling was performed at the convection pass outlet of SBS under normal air firing and oxy-combustion conditions, and the samples are currently being analyzed at Western Kentucky University.

Task 3 (Techno-Economic Study) has been concluded in the current quarter. The simulation and cost estimate work performed on the 533MWe Pulverized Coal (PC) air- and oxyfired in Q1 2004 was extended to $250 \mathrm{MW}_{\mathrm{e}}$ and 1,000MW $\mathrm{M}$ plant size cases and are compared to IGCC system.

Techno-economic analyses showed that compared to the new air-blown PC plant without $\mathrm{CO}_{2}$ capture, the cost of electricity (COE) of the oxycombustion process increased by about 25$30 \%$, while that of the MEA-equipped air-blown PC plant increased by about $60 \%$ and that of the Selexol-equipped IGCC plant increased by $20 \%$. The cost of the oxycombustion process is slightly higher than the IGCC plant, but is more competitive than the MEA-equipped air-blown PC plant.

The Oxycombustion process and MEA process are technically applicable for plant retrofit to capture CO2 emissions. For a 533MWe power plant, the Oxycombustion retrofit required less than $\$ 300 / \mathrm{kWe}$ capital cost and increased 5 mills $/ \mathrm{kWh}$ O\&M cost. For the same 
plant size, the MEA retrofit required $\$ 460 / \mathrm{kWe}$ capital cost and $11 \mathrm{mills} / \mathrm{kWh}$ O\&M cost. The Oxycombustion process is economically favorable for the $\mathrm{CO} 2$ capture retrofit of the existing power plant.

Task 4 (Boiler Design) had been initiated in the last quarter (Q1 2004). The scope of work (SOW) to be performed had been modified as per DOE request and the updated SOW had been reported. Engineering calculations are in progress and the results will soon be reported.

The project main results have been presented in conferences in April and May 2004.

The current work schedule is to analyze the mercury samples and to review the experimental data collected during the entire 2003-2004 test campaign. The report summarizing the work performed in the Techno-Economic study (task 3) will be completed, and will report conclusions regarding oxycombustion competitiveness vs air-blown system with amine scrubbing and vs IGCC. Preliminary results on engineering effort currently in progress in the boiler design task (task 4) will be reported.

Out of the $\sim \$ 785 \mathrm{k}$ DOE cost-share allocated in this project, $\$ 545 \mathrm{k}$ have been spent to date, mainly in site preparation $(\sim 376 \mathrm{k})$, test performance $(\sim 111 \mathrm{k})$ and economics assessment ( $\sim 41)$. In addition to DOE allocated funds, to date approximately $\$ 400 \mathrm{k}$ has been cost-shared by the participants, bringing the total project cost up to $\$ 945 \mathrm{k}$ as on June 30, 2004. 


\section{EXPERIMENTAL}

During this reporting period, the participants have mainly worked on Task 2 (Test Performance), Task 3 (Techno-Economic Assessment) and Task 4 (Conceptual Boiler Design) of the project.

\section{TASK 1: SITE PREPARATION}

Task 1 has been completed in the previous reporting period. The resulting final configuration of the pilot boiler has been described.

\section{TASK 2: COMBUSTION AND EMISSIONS PERFORMANCE OPTIMIZATION}

The following subsections summarize the preliminary results obtained from the tests performed in 2003 and describe the tests performed in current reporting period. Preliminary results of those latest tests are reported and analyzed in the next section of this report "RESULTS AND DISCUSSION”.

\subsection{Summary of conclusions from previous reporting periods}

In previous reporting period, the following results had been obtained:

- The participants had demonstrated the feasibility of $100 \%$ air replacement by oxygenenriched flue gas on the $1.5 \mathrm{MW}_{\text {th }}$ coal-fired boiler.

- The air infiltrations had been reduced to approximately $5 \%$ of the stoichiometry, enabling to reach around $80 \%$ of $\mathrm{CO}_{2}$ in the flue gases.

- The flue gas volume exiting the boiler has been reduced by $70 \%$ thus making easier any additional flue gas treatment which may be necessary before stack exhaust or $\mathrm{CO}_{2}$ reuse or sequestration.

- The $\mathrm{NO}_{\mathrm{x}}$ emissions had been shown considerably lower in $\mathrm{O}_{2}$-fired conditions than in airbaseline, the reduction rate averaging 70\%. NOx emissions is also impacted by oxygen flow rate into the primary air zone and by flue gas overall recirculation rate. The recirculated flue gas flow rate has been varied from $80 \%$ to $95 \%$ of total flue gas flow, and the total oxygen flow rate into the primary air zone of the boiler had been set to levels ranging from $15 \%$ to $25 \%$ of the total oxygen consumption in the overall combustion. The influence of those two parameters on NOx emission can be explained by temperature increase resulting from increased $\mathrm{O}_{2}$ content in primary air zone or from lower flue gas flow. Such higher temperature in the reducing zone of the boiler promotes the conversion of recirculated NOx and devolatilized fuel nitrogen to molecular nitrogen.

- A stable flame had been obtained, with similar shape as in air-firing operation. From a visual judgment, the oxy-fired flame was colder than air-fired flame, presumably because of higher $\mathrm{CO}_{2}$ specific heat.

- Furnace exit flame temperature (FEGT) and convection pass exit gas temperature (CPEGT) have been measured and compared in under oxy-firing than under air-firing 
conditions. While lower FEGT was measured under oxy-firing conditions, the CPEGT was generally higher. Further studies are required to address boiler heat transfer and steam generation characteristics.

\subsection{Tests performed during the reporting period}

Additional full-oxy combustion optimization tests have been performed in this quarter totaling 5 days of experimental data gathering.

In addition to flue gas composition $\left(\mathrm{NO}_{\mathrm{x}}, \mathrm{SO}_{\mathrm{x}}, \mathrm{CO}, \mathrm{CO}_{2}, \mathrm{O}_{2}\right)$ and Furnace Exit Gas Temperature (FEGT), the following measurement have been performed, both on air-blown flame and on oxy-flame:

- In-furnace gas temperature measurement to evaluate heat transfer in the boiler and convection pass

- Flame emissivity measurement

- Mercury emission measurement

\section{TASK 3: TECHNO-ECONOMIC STUDY}

In the scope of the techno-economics task of the project, process calculation and economics assessment are performed to compare various $\mathrm{CO}_{2}$ capture technologies.

Three technologies are considered:

- Air-blown pulverized coal (PC) power plants with amine scrubbing

- Oxy-fired PC power plants with flue gas recirculation, also referred to as Oxycombustion process, or Oxygen Enhanced Combustion (OEC)

- IGCC units with Selexol for $\mathrm{CO}_{2}$ capture

Air-blown and oxy-fired processes may be considered for both new and retrofit coal-fired applications. IGCC unit only apply to new units.

In $\mathrm{Q}_{3}$ 2003, the various cases to be assesses (plant type, plant capacity, flue gas treatment technologies...) have been described, as well as the methodology to be applied for mass and energy balance calculation and cost assessment.

In $\mathrm{Q}_{4}$ 2003, the power generation costs assessments have been performed for a specific plant gross capacity of 533MWe. Plants burning PRB coal under OEC process and conventional air-blown PC have been investigated.

In Q1 2004, More detailed process and cost calculations have been performed on the 533MWe air and oxy-fired PC units. Revised capital costs and power consumption data for ASU were included. Also, calculations were performed on two IGCC units (273 and 535MWe

In the current reporting period, the following progress has been made for the process schematics that were described in Q1 2004 quarterly report:

- The process and cost calculations for air and oxy-fired PC units are extended to $250 \mathrm{MW}_{\mathrm{e}}$ and $1,000 \mathrm{MW}_{\mathrm{e}}$ plant sizes from the previously performed $533 \mathrm{MW}_{\mathrm{e}}$ case. As the impact of oxygen purity was not significant on $\mathrm{CO}_{2}$ avoided costs for $95 \%$ and 
99\% purity, only 99\% purity oxygen case was considered for 250 and 1,000MWe cases to obtain richer $\mathrm{CO}_{2}$ flue has.

- Impact of plant capacity on electricity costs and $\mathrm{CO}_{2}$ avoided costs were performed.

- Different technology options for $\mathrm{CO}_{2}$ capture $\left(\mathrm{O}_{2}-\mathrm{CO}_{2}\right.$, MEA and IGCC) were compared on both technical and economical perspectives.

The latest results are reported in the "results and discussion" section of this report.

In summary, the techno-economic analysis (Task 3) in the scope of the project is completed. Presently, results are being refined.

Table 1shows the scenarios of the techno-economic analysis performed.

\begin{tabular}{|c|l|}
\hline & Approximate size, MWe \\
\hline Air combustion, Baseline & \\
\hline Without $\mathrm{CO}_{2}$ separation & $250,500,1000$ \\
\hline With the $\mathrm{MEA} \mathrm{process}$ & $250,500,1000$ \\
\hline OEC combustion & \\
\hline Wet $\mathrm{O}_{2} / \mathrm{CO}_{2}$ recycle & $250,500,1000$ \\
\hline Dry $\mathrm{O}_{2} / \mathrm{CO}_{2}$ recycle & $250,500,1000$ \\
\hline IGCC & 250,500 \\
\hline
\end{tabular}

Table 1: Scenarios for techno-economic analysis

\section{TASK 4: CONCEPTUAL BOILER DESIGN}

The aim of this task is to provide a conceptual design for a boiler operating on oxygen. This study will investigate the achievable boiler size reduction using oxygen-combustion instead of air-combustion.

The specification of this task has been modified as per DOE request. The updated scope of work has been reported in the previous quarterly report. This task now includes two sub-tasks "Subtask 4.1 Recommendations for retrofit applications" and "Subtask 4.2 Preliminary Design of a New Generation Boiler”.

The scope of the engineering study 4.2 is to determine the conceptual design of an oxygen-fired boiler with minimum flue gas recirculation. Cyclone firing is being considered a prime candidate since its slagging characteristics are suitable with hot oxygen combustion.

The boiler performance calculations are in progress, and corresponding results will be provided in further reports. 


\section{RESULTS AND DISCUSSION}

Preliminary experimental results from June latest tests are reported. Detailed results analysis of the entire test campaign (2003-2004) will be provided in future reports.

Results from process and cost calculations on air and oxy-fired units performed on 533MWe plant capacity are extended for 250MWe and 1,000MWe cases. Impact of plant capacity has been assessed. Different oxy-fired plant configurations are compared with MEA and IGCC and are reported.

As reported in "Experimental Section", the boiler design calculations are in progress and results will be reported in future reports.

Finally project management update is provided in the following "Project Schedule" and "Financial Status" subsections.

\section{TASK 2: COMBUSTION AND EMISSIONS PERFORMANCE OPTIMIZATION}

As stated in "Experimental" section of this report, additional measurement have been performed on the oxy-flame and compared air-flame results.

Several interesting results were obtained in regard to the flame shape, temperature and emissivity. Although these results are yet to be fully analyzed and discussed, the highlights are as follows.

\subsection{Switching procedure from air-fired to oxygen-fired operation}

During these tests the overall mass flow rate of the combustible gases and oxidizers in the combustion zone has been maintained when air was switched to flue gas and oxygen.

The switching of primary air to oxygen-enriched flue gas is initially performed with the addition of oxygen only through a lance at the burner. After all primary air was substituted with flue gas, and all oxygen was introduced through the lance, then some oxygen was removed from the lance to be introduced in the primary air line via an oxynator. The oxygen to the secondary air and overfire air port is introduced through an oxynator.

\subsection{Overall Combustion characteristics in $\mathrm{O}_{2} / \mathrm{CO}_{2}$ environment - burner stoichiometry}

As reported in the past progress report (and summarized in "Experiment" 2.1), during the previous tests we had noticed that the oxy-combustion flame was colder than the flame with air. The flame was judged to be cooler by visual observations and Flame View measurements. During these recent tests the coal feed system had been improved providing a very smooth combustion condition with very small convective pass exit $\mathrm{O}_{2}$ fluctuations. As we switched from air firing to oxy-combustion while maintaining a flame stoichiometry of approximately 0.85, the combustion was affected negatively, judging from the high CO levels observed. We knew that the burner velocities were lower since nitrogen was substituted by $\mathrm{CO}_{2}$. We could not reduce the burner throat since the unit needs to be able to start-up on air before switching to oxygen. Therefore, we increased the burner stoichiometry from 0.85 to 1.0-1.05 resulting in increased burner velocity. The combination effect of higher burner stoichiometry and velocity 
resulted in a more stable and brighter flame. The staged oxy-combustion was originally considered as a means to control the $\mathrm{NO}_{\mathrm{x}}$ emissions. Fortunately, we learned that oxycombustion is much more insensitive to burner stoichiometry (in the range of 0.8 to 1.05) than normal air firing. $\mathrm{NO}_{\mathrm{x}}$ emissions were always below $0.1 \mathrm{lb}$ per million Btu during the oxycombustion. The reason being that a large amount of $\mathrm{NO}_{\mathrm{x}}$ is recirculated to the burner with the flue gas recirculation where they are destroyed by the reburn mechanism.

\subsection{Emmissivity Measurement}

The measured emissivity also indicated that the flame emissivity under the oxycombustion is similar to the flame emissivity under normal air firing. These first-of-a-kind measurements enabled us to more accurately determine the boiler performance under oxycombustion conditions.

\subsection{Temperature Measurement}

Temperature measurements were performed at the flame, furnace exit, and the convection pass outlet for both air firing and oxy-firing, while the overall mass flow rate was kept constant. The data is being analyzed, but our pilot results seem to indicate that the temperature profiles are similar under oxy-firing conditions. In the previous tests, the average FEGT with oxy-firing was lower by $70^{\circ} \mathrm{F}$ than with air firing.

\subsection{Mercury Measurement}

Mercury sampling was performed at the convection pass outlet of SBS under normal air firing and oxy-combustion conditions, and currently the samples are being analyzed at Western Kentucky University.

\section{TASK 3: TECHNO-ECONOMIC STUDY}

The following sub-sections report the simulation results and cost assessment obtained for:

- $250 \mathrm{MW}_{\mathrm{e}}$ and $1,000 \mathrm{MW}_{\mathrm{e}}$ plant cases for both air fired and oxy-fired scenarios and comparison to the previously performed $533 \mathrm{MW}_{\mathrm{e}}$ case for $99 \%$ oxygen purity case

- Overall process performances of air-fired PC boiler cases with and without MEA

- Overall process performances of oxy-fired PC boiler cases

\subsection{AIR BLOWN PC BOILER CASES WITH AND WITHOUT $\mathrm{CO}_{2}$ REMOVAL}

\subsubsection{Process simulation}

In process simulation, a power plant was divided into three main process areas that include the combustion system, steam turbine system and gas cleaning system. The combustion system is the same for both the conventional PC plant and the plant installed with an MEA unit. However, the steam turbine system is different between these two types of plants. In the plant with the MEA unit, a significant part of steam is drawn from the turbine for amine regeneration; the flow chart of the steam turbine simulation was modified correspondingly. The simulation for the MEA process was conducted in less detail, only for calculation of the basic mass and heat flows. Its performance equations defining the functional relationships among various key 
operating parameters have been regressed from the data obtained from the process simulation in a DOE project ${ }^{[10]}$. The compression and further purification of the $\mathrm{CO}_{2}$-rich stream are not simulated in this study. Some main process parameters are listed in Table 2.

\begin{tabular}{|c|c|c|c|c|c|c|}
\hline \multirow[b]{2}{*}{ Gross kWe (terminal) } & \multicolumn{3}{|c|}{ Conventional PC W/O CO${ }_{2}$ capt. } & \multicolumn{3}{|c|}{ PC plant + MEA } \\
\hline & 266,380 & 533,230 & $1,053,570$ & 217,350 & 434,850 & 859,410 \\
\hline \multicolumn{7}{|l|}{ Combustion } \\
\hline Air/ $\mathrm{O}_{2}$ equivalent ratio, / & 1.15 & 1.15 & 1.15 & 1.15 & 1.15 & 1.15 \\
\hline Air flow rate, $\mathrm{lb} / \mathrm{h}$ & $2,007,884$ & $4,029,474$ & $7,949,303$ & $2,007,884$ & $4,029,474$ & $7,949,303$ \\
\hline $\mathrm{O}_{2} / \mathrm{Ar}$ flow rate, $\mathrm{lb} / \mathrm{h}$ & $\mathrm{n} / \mathrm{a}$ & $\mathrm{n} / \mathrm{a}$ & $\mathrm{n} / \mathrm{a}$ & $\mathrm{n} / \mathrm{a}$ & $\mathrm{n} / \mathrm{a}$ & $\mathrm{n} / \mathrm{a}$ \\
\hline Coal feed rate, $\mathrm{lb} / \mathrm{h}$ & 261,598 & 524,982 & $1,035,679$ & 261,598 & 524,982 & $1,035,679$ \\
\hline Flue gas recycle ratio, $\mathrm{lb} / \mathrm{h}$ & $\mathrm{n} / \mathrm{a}$ & $\mathrm{n} / \mathrm{a}$ & $\mathrm{n} / \mathrm{a}$ & $\mathrm{n} / \mathrm{a}$ & $\mathrm{n} / \mathrm{a}$ & $\mathrm{n} / \mathrm{a}$ \\
\hline \multicolumn{7}{|l|}{ Steam generation } \\
\hline Hot reheat steam, lb/h & $1,511,807$ & $3,022,125$ & $5,979,534$ & $1,511,807$ & $3,022,125$ & $5,979,534$ \\
\hline Superheat steam, lb/h & $1,703,981$ & $3,422,824$ & $6,739,628$ & $1,703,981$ & $3,422,824$ & $6,739,628$ \\
\hline IP steam to MEA process & $\mathrm{n} / \mathrm{a}$ & $\mathrm{n} / \mathrm{a}$ & $\mathrm{n} / \mathrm{a}$ & 733,088 & $1,470,914$ & $2,902,335$ \\
\hline Steam condensate, lb/h & $1,401,567$ & $2,802,051$ & $5,543,513$ & 668,479 & $1,331,136$ & $2,641,178$ \\
\hline Main feedwater, lb/h & $1,660,496$ & $3,321,228$ & $6,567,636$ & $1,660,496$ & $3,321,228$ & $6,567,636$ \\
\hline Heat duty of cooling tower, $10^{6} \mathrm{Btu} / \mathrm{h}$ & 1,090 & 2,178 & 4,310 & 519 & 1,034 & 2,051 \\
\hline \multicolumn{7}{|l|}{ Flue gas for boiler system } \\
\hline Flue gas volume, $\mathrm{lb} / \mathrm{h}$ & $2,255,746$ & $4,526,825$ & $8,930,601$ & $2,255,746$ & $4,526,825$ & $8,930,601$ \\
\hline Flue gas temperature, ${ }^{0} \mathrm{~F}$ & 295 & 295 & 295 & 295 & 295 & 295 \\
\hline \multicolumn{7}{|l|}{ Composition: } \\
\hline $\mathrm{N}_{2}$, vol\% & $71.61 \%$ & $71.62 \%$ & $71.61 \%$ & $71.61 \%$ & $71.62 \%$ & $71.61 \%$ \\
\hline $\mathrm{O}_{2}$, vol\% & $2.49 \%$ & $2.49 \%$ & $2.49 \%$ & $2.49 \%$ & $2.49 \%$ & $2.49 \%$ \\
\hline $\mathrm{CO}_{2}$, vol\% & $14.55 \%$ & $14.55 \%$ & $14.55 \%$ & $14.55 \%$ & $14.55 \%$ & $14.55 \%$ \\
\hline $\mathrm{H}_{2} \mathrm{O}$, vol\% & $11.15 \%$ & $11.15 \%$ & $11.15 \%$ & $11.15 \%$ & $11.15 \%$ & $11.15 \%$ \\
\hline $\mathrm{Ar}, \mathrm{vol} \%$ & 0 & 0 & 0 & 0 & 0 & 0 \\
\hline $\mathrm{SO}_{2}, \mathrm{vol} \%$ & $0.03 \%$ & $0.03 \%$ & $0.03 \%$ & $0.03 \%$ & $0.03 \%$ & $0.03 \%$ \\
\hline $\mathrm{NO}_{\mathrm{x}}, \mathrm{lb} / \mathrm{MMBtu}$ & 0.5 & 0.5 & 0.5 & 0.5 & 0.5 & 0.5 \\
\hline Fly ash flow rate, lb/h & 10,987 & 22,049 & 43,499 & 10,987 & 22,049 & 43,499 \\
\hline
\end{tabular}

Table 2: Main operating parameters of the air-blown PC plants

Certain components of the power plant, such as pumps and conveyors, consume significant amounts of electricity. The auxiliary power use of the coal handling, pulverizer, ash handling and miscellaneous systems were scaled linearly from the reference plant based on the amount of solid flow or the plant size. For all other main components, energy usage was obtained from the process simulation. It is found that the auxiliary power usage of individual process components are almost linearly proportional to the plant scale. The results of the auxiliary power use are summarized in Table 3. For an air-blown PC plant without $\mathrm{CO}_{2}$ capture, the total auxiliary use of electricity is about $6 \%$ of the total gross electricity output. The installation of the MEA process reduced a gross electricity output by $20 \%$, compared to the conventional plant without $\mathrm{CO}_{2}$ capture. This is due to the loss of a significant part of steam used to supply heat for amine regeneration, which otherwise is used for generating electricity. In addition, the gas 
induced fan and amine recirculation pump in the MEA process consumed more than $1 / 3$ of the total auxiliary power usage. As a result, the total auxiliary power usage increased to $10 \%$ of the total gross output in the PC plant equipped with the MEA process.

\begin{tabular}{|l|r|r|r|r|r|r|}
\hline & \multicolumn{2}{|c|}{ Air-blown PC W/O CO $\mathbf{~}_{\mathbf{2}}$ capture } & \multicolumn{3}{|c|}{ Air-blown PC+MEA } \\
\hline Gross output (terminal), kWe & $\mathbf{2 6 6 , 3 8 0}$ & $\mathbf{5 3 3 , 2 3 0}$ & $\mathbf{1 , 0 5 3 , 5 7 0}$ & $\mathbf{2 1 7 , 3 5 0}$ & $\mathbf{4 3 4 , 8 5 0}$ & $\mathbf{8 5 9 , 4 1 0}$ \\
\hline Auxillary load, kWe & & & & & & \\
\hline Coal handling & 169 & 339 & 670 & 169 & 339 & 670 \\
\hline Pulverizers & 1,463 & 2,937 & 5,793 & 1,463 & 2,937 & 5,793 \\
\hline Primary air fans & 603 & 1,212 & 2,388 & 603 & 1,212 & 2,388 \\
\hline Forced Draft fans & 574 & 1,154 & 2,274 & 574 & 1,154 & 2,274 \\
\hline Induced draft fans & 2,569 & 5,122 & 10,173 & 2,569 & 5,122 & 10,173 \\
\hline Seal air blowers & 23 & 46 & 90 & 23 & 46 & 90 \\
\hline Steam turbine auxiliaries & 441 & 884 & 1,748 & 441 & 884 & 1,748 \\
\hline Condensate pumps & 475 & 949 & 1,878 & 445 & 891 & 1,763 \\
\hline * Main feed pump & 5,468 & 10,938 & 21,629 & 5,468 & 10,938 & 21,629 \\
\hline Circulating water pumps & 2,094 & 4,187 & 8,283 & 999 & 1,989 & 3,946 \\
\hline Cooling tower fans & 1,184 & 2,367 & 4,684 & 565 & 1,125 & 2,232 \\
\hline Ash handling & 710 & 1,424 & 2,809 & 710 & 1,424 & 2,809 \\
\hline Miscellaneous & 1,383 & 2,411 & 4,160 & 1,383 & 2,411 & 4,160 \\
\hline Transformer loss & 722 & 1,215 & 2,026 & 722 & 1,215 & 2,026 \\
\hline ESP & 657 & 1,319 & 2,602 & 657 & 1,319 & 2,602 \\
\hline LSD & 1,750 & 3,500 & 7,000 & 1,750 & 3,500 & 7,000 \\
\hline SCR & 1,375 & 2,750 & 5,500 & 1,375 & 2,750 & 5,500 \\
\hline MEA: gas induced fan & 0 & 0 & 0 & 7,892 & 15,837 & 31,244 \\
\hline amine pump & 0 & 0 & 0 & 1,485 & 2,980 & 5,879 \\
\hline ACI & 50 & 99 & 196 & 50 & 99 & 196 \\
\hline Sub-total & $\mathbf{1 6 , 2 4 1}$ & $\mathbf{3 1 , 9 1 6}$ & $\mathbf{6 2 , 2 7 4}$ & $\mathbf{2 3 , 8 7 4}$ & $\mathbf{4 7 , 2 3 4}$ & $\mathbf{9 2 , 4 9 3}$ \\
\hline
\end{tabular}

Table 3: Auxiliary power use in the air-blown PC plants with and without $\mathrm{CO}_{2}$ capture

\subsubsection{Performance summary}

The overall process performances for the air-blown PC plants without and with $\mathrm{CO}_{2}$ capture are shown in Table 4. The power generation efficiency for the sub-critical PC plant without $\mathrm{CO}_{2}$ capture is about $37 \%$, and remains the same for the different plant capacities investigated. When the MEA unit is installed for $\mathrm{CO}_{2}$ capture, the generation efficiency drops to about $28.6 \%$. In terms of the net electricity output, about $25 \%$ is lost due to the installation of the MEA unit. If the power use for $\mathrm{CO}_{2}$ compression is included, these values will even become larger.

\begin{tabular}{|l|r|r|r|r|r|r|}
\hline & \multicolumn{2}{|c|}{ W/O $\mathbf{C O}_{2}$ Capture } & \multicolumn{3}{|c|}{ With the MEA } \\
\hline Gross output (terminal), kWe & $\mathbf{2 6 6 , 3 8 0}$ & $\mathbf{5 3 3 , 2 3 0}$ & $\mathbf{1 , 0 5 3 , 5 7 0}$ & $\mathbf{2 1 7 , 3 5 0}$ & $\mathbf{4 3 4 , 8 5 0}$ & $\mathbf{8 5 9 , 4 1 0}$ \\
\hline Coal Flow Rate (lb/hr) & 261598 & 524982 & 1035679 & 261598 & 524982 & 1035679 \\
\hline Steam Turbine Power (MWe) & 266.4 & 533.2 & 1053.6 & 217.4 & 434.9 & 859.4 \\
\hline Aux. Power (MWe) & 16.2 & 31.9 & 62.3 & 23.9 & 47.2 & 92.5 \\
\hline Net Power (MWe) & $\mathbf{2 5 0 . 1}$ & $\mathbf{5 0 1 . 3}$ & $\mathbf{9 9 1 . 3}$ & $\mathbf{1 9 3 . 5}$ & $\mathbf{3 8 7 . 6}$ & $\mathbf{7 6 6 . 9}$ \\
\hline Net efficiency, HHV (\%) & $37.00 \%$ & $37.00 \%$ & $37.10 \%$ & $28.60 \%$ & $28.60 \%$ & $28.70 \%$ \\
\hline
\end{tabular}

Table 4: Overall process performances of air-blown PC plants 


\subsection{OXY-FIRED PC BOILER CASES}

\subsubsection{Process simulation}

The process simulation was conducted separately for three process areas, i.e., the combustion system, steam turbine system and gas cleaning system. The air separation unit (ASU) was not simulated because the related data has been available. The other process components specific to the OEC process, such as the $\mathrm{O}_{2} / \mathrm{CO}_{2}$ flue gas recycle and flue gas condensation, are included in the simulation. The compression and further purification of the $\mathrm{CO}_{2}$-rich stream is not simulated. A $99 \% \mathrm{O}_{2}$ purity from the ASU was mainly assumed in the simulation, while a $95 \% \mathrm{O}_{2}$ purity was used only in a case for comparison. The main process parameters are listed in Table 5.

\begin{tabular}{|c|c|c|c|c|c|c|}
\hline \multirow[b]{2}{*}{ Gross output, MWe } & \multicolumn{3}{|c|}{ Wet OEC } & \multicolumn{3}{|c|}{ Dry OEC } \\
\hline & 266,380 & 533,230 & $1,053,570$ & 266,380 & 533,230 & $1,053,570$ \\
\hline \multicolumn{7}{|l|}{ Combustion } \\
\hline $\mathrm{O}_{2} /$ fuel equivalent ratio, lb/h & 1.03 & 1.03 & 1.03 & 1.03 & 1.03 & 1.03 \\
\hline $\mathrm{O}_{2}$ flow rate (99\% purity), lb/h & 407,741 & 817,540 & $1,600,007$ & 420,296 & 843,885 & $1,663,566$ \\
\hline Coal feed rate, lb/h & 252,670 & 506,615 & 991,497 & 260,450 & 522,941 & $1,030,883$ \\
\hline Flue gas recycle ratio, lb/h & $71.60 \%$ & $71.60 \%$ & $71.60 \%$ & $75.10 \%$ & $75.10 \%$ & $75.10 \%$ \\
\hline \multicolumn{7}{|l|}{ Steam generation } \\
\hline Hot reheat steam, lb/h & $1,511,807$ & $3,022,125$ & $5,979,534$ & $1,511,807$ & $3,022,125$ & $5,979,534$ \\
\hline Superheat steam, lb/h & $1,703,981$ & $3,422,824$ & $6,739,628$ & $1,703,981$ & $3,422,824$ & $6,739,628$ \\
\hline IP steam to MEA process & $\mathrm{n} / \mathrm{a}$ & $\mathrm{n} / \mathrm{a}$ & $\mathrm{n} / \mathrm{a}$ & $\mathrm{n} / \mathrm{a}$ & $\mathrm{n} / \mathrm{a}$ & $\mathrm{n} / \mathrm{a}$ \\
\hline Steam condensate, $\mathrm{lb} / \mathrm{h}$ & $1,401,567$ & $2,802,051$ & $5,543,513$ & $1,401,567$ & $2,802,051$ & $5,543,513$ \\
\hline Main feedwater, lb/h & $1,660,496$ & $3,321,228$ & $6,567,636$ & $1,660,496$ & $3,321,228$ & $6,567,636$ \\
\hline Heat duty of cooling tower, mBtu/h & 1,090 & 2,178 & 4,310 & 1,090 & 2,178 & 4,310 \\
\hline \multicolumn{7}{|l|}{ Flue gas for cleaning } \\
\hline Flue gas volume, $\mathrm{b} / \mathrm{h}$ & 647,151 & $1,297,622$ & $2,543,667$ & 553,563 & $1,111,510$ & 2,191,106 \\
\hline Flue gas temperature, oF & 395 & 395 & 395 & 295 & 295 & 295 \\
\hline \multicolumn{7}{|l|}{ Composition: } \\
\hline $\mathrm{N}_{2}, \mathrm{vol} \%$ & $0.34 \%$ & $0.34 \%$ & $0.34 \%$ & $0.49 \%$ & $0.49 \%$ & $0.49 \%$ \\
\hline $\mathrm{O}_{2}, \mathrm{vol} \%$ & $2.27 \%$ & $2.27 \%$ & $1.86 \%$ & $3.28 \%$ & $3.28 \%$ & $3.28 \%$ \\
\hline $\mathrm{CO}_{2}, \mathrm{vol} \%$ & $54.72 \%$ & $54.72 \%$ & $55.02 \%$ & $79.26 \%$ & $79.26 \%$ & $79.26 \%$ \\
\hline $\mathrm{H}_{2} \mathrm{O}, \mathrm{vol} \%$ & $41.93 \%$ & $41.93 \%$ & $42.04 \%$ & $15.90 \%$ & $15.90 \%$ & $15.90 \%$ \\
\hline Ar, vol\% & $0.64 \%$ & $0.64 \%$ & $0.64 \%$ & $0.93 \%$ & $0.93 \%$ & $0.93 \%$ \\
\hline $\mathrm{SO}_{2}, \mathrm{vol} \%$ & $0.10 \%$ & $0.10 \%$ & $0.10 \%$ & $0.14 \%$ & $0.14 \%$ & $0.14 \%$ \\
\hline $\mathrm{NO}_{\mathrm{x}}, \mathrm{lb} / \mathrm{MMBtu}$ & 0.15 & 0.15 & 0.15 & 0.15 & 0.15 & 0.15 \\
\hline Fly ash flow rate, $\mathrm{lb} / \mathrm{h}$ & 10612 & 21,278 & 41643 & 10939 & 21964 & 43297 \\
\hline \multicolumn{7}{|l|}{ Flue gas after cleaning } \\
\hline Flue gas volume, b/h & 500,246 & 997,016 & $1,965,081$ & 515,625 & $1,031,076$ & $2,041,339$ \\
\hline Flue gas temperature, oF & 68 & 68 & 68 & 68 & 68 & 68 \\
\hline \multicolumn{7}{|l|}{ Composition: } \\
\hline $\mathrm{N}_{2}, \mathrm{vol} \%$ & $0.57 \%$ & $0.57 \%$ & $0.58 \%$ & $0.57 \%$ & $0.58 \%$ & $0.57 \%$ \\
\hline $\mathrm{O}_{2}, \mathrm{vol} \%$ & $3.83 \%$ & $3.83 \%$ & $3.14 \%$ & $3.82 \%$ & $3.83 \%$ & $3.82 \%$ \\
\hline $\mathrm{CO}_{2}, \mathrm{vol} \%$ & $92.84 \%$ & $92.83 \%$ & $93.53 \%$ & $92.85 \%$ & $92.83 \%$ & $92.86 \%$ \\
\hline $\mathrm{H}_{2} \mathrm{O}$, vol\% & $1.64 \%$ & $1.65 \%$ & $1.64 \%$ & $1.64 \%$ & $1.64 \%$ & $1.64 \%$ \\
\hline Ar, vol\% & $1.09 \%$ & $1.09 \%$ & $1.09 \%$ & $1.09 \%$ & $1.10 \%$ & $1.09 \%$ \\
\hline $\mathrm{SO}_{2}, \mathrm{vol} \%$ & $0.02 \%$ & $0.02 \%$ & $0.02 \%$ & $0.02 \%$ & $0.02 \%$ & $0.02 \%$ \\
\hline
\end{tabular}

Table 5: Main operating parameters of the OEC processes (99\% purity O2 used) 
From the process simulation, the auxiliary power usage of the main equipment in the OEC plant was also obtained as listed in Table 6. The ASU for $\mathrm{O}_{2}$ production consumed a considerable amount of electricity, contributing to $80 \%$ of the total auxiliary power. This is based on the specific energy consumption of $0.394 \mathrm{kWh} / \mathrm{Nm}^{3}$ pure $\mathrm{O}_{2}$, independent of the $\mathrm{O}_{2}$ purity (99\% or $95 \%$ ), according to the Air Liquide. The $\mathrm{O}_{2} / \mathrm{CO}_{2}$ flue gas recycle and the condenser consumed another $2.5 \%$ of the total auxiliary power. The auxiliary power required for the gas cleaning units and induced draft fan decreased due to the reduced flue gas volume in the OEC process. Overall, the auxiliary power in the OEC process accounted for about $24 \%$ of the gross output, compared to $6 \%$ in the conventional air-blown PC plant.

\begin{tabular}{|l|r|r|r|r|r|r|}
\hline & \multicolumn{3}{|c|}{ Wet OEC } & \multicolumn{3}{|c|}{ Dry OEC } \\
\hline Gross output (terminal), kWe & $\mathbf{2 6 6 , 3 8 0}$ & $\mathbf{5 3 3 , 2 3 0}$ & $\mathbf{1 , 0 5 3 , 5 7 0}$ & $\mathbf{2 6 6 , 3 8 0}$ & $\mathbf{5 3 3 , 2 3 0}$ & $\mathbf{1 , 0 5 3 , 5 7 0}$ \\
\hline \hline Auxiliary load summary, kWe & & & & & & \\
\hline Coal handling & 163 & 328 & 641 & 168 & 338 & 667 \\
\hline Pulverizers & 1,413 & 2,834 & 5,546 & 1,457 & 2,925 & 5,767 \\
\hline Primary air fans & 613 & 1,221 & 2,407 & 594 & 1,192 & 2,350 \\
\hline Forced Draft fans & 583 & 1,163 & 2,292 & 565 & 1,135 & 2,238 \\
\hline Induced draft fans & 737 & 1,470 & 2,897 & 631 & 1,266 & 2,496 \\
\hline Seal air blowers & 23 & 46 & 90 & 22 & 45 & 88 \\
\hline Steam turbine auxiliaries & 441 & 884 & 1,748 & 441 & 884 & 1,748 \\
\hline Condensate pumps & 475 & 949 & 1,878 & 475 & 949 & 1,878 \\
\hline$*$ Main feed pump & 5,468 & 10,938 & 21,629 & 5,468 & 10,938 & 21,629 \\
\hline Circulating water pumps & 2,094 & 4,187 & 8,283 & 2,094 & 4,187 & 8,283 \\
\hline Cooling tower fans & 1,184 & 2,367 & 4,684 & 1,184 & 2,367 & 4,684 \\
\hline Ash handling & 685 & 1,374 & 2,690 & 706 & 1,419 & 2,796 \\
\hline Miscellaneous & 1,383 & 2,411 & 4,160 & 1,383 & 2,411 & 4,160 \\
\hline Transformer loss & 722 & 1,215 & 2,026 & 722 & 1,215 & 2,026 \\
\hline ESP & 189 & 376 & 741 & 161 & 324 & 638 \\
\hline LSD & 502 & 998 & 1,994 & 429 & 859 & 1,717 \\
\hline ACI & 14 & 28 & 56 & 12 & 24 & 48 \\
\hline OEC auxiliary & & & & & & \\
\hline Flue gas recycle fan & 911 & 1,817 & 3,581 & 766 & 1,540 & 3,258 \\
\hline Recycle gas condenser pump & 0 & 0 & 0 & 308 & 768 & 1,228 \\
\hline Flue gas condenser pump & 257 & 507 & 1,015 & 98 & 157 & 391 \\
\hline Flue gas water spray cooling & 263 & 526 & 1,031 & 0 & 0 & 0 \\
\hline ASU & 50,413 & 101,081 & 197,826 & 51,966 & 104,339 & 205,685 \\
\hline Sub-total & $\mathbf{6 3 , 0 6 6}$ & $\mathbf{1 2 5 , 7 8 2}$ & $\mathbf{2 4 5 , 5 8 6}$ & $\mathbf{6 4 , 1 8 3}$ & $\mathbf{1 2 8 , 3 4 4}$ & $\mathbf{2 5 2 , 1 4 6}$ \\
\hline
\end{tabular}

Table 6: Auxiliary power usage in the oxy-combustion processes

\subsubsection{Performance summary}

Table 7 lists the overall performances of the OEC power plants. Due to as high as $20 \%$ of the gross power output consumed for oxygen production, the generation efficiency of the OEC process drops to a range of $30-32 \%$, compared to about $37 \%$ in the conventional air-blown plant without $\mathrm{CO}_{2}$ capture. However, the OEC process is much more efficient than the air-blown plant installed with the MEA unit. The dry OEC process has a generation efficiency slightly lower than the wet OEC process since a small amount of heat is lost during condensation in the flue gas recycle loop. 


\begin{tabular}{|l|c|c|c|c|c|c|}
\hline & \multicolumn{3}{|c|}{ Wet OEC } & \multicolumn{3}{c|}{ Dry OEC } \\
\hline Gross output (terminal), MW & 266,380 & 533,230 & $1,053,570$ & 266,380 & 533,230 & $1,053,570$ \\
\hline & & & & & & \\
\hline Coal Flow Rate (lb/hr) & 252670 & 503044 & 991497 & 260450 & 522941 & 1030883 \\
\hline Steam Turbine Power (MWe) & 266.4 & 533.2 & 1053.6 & 266.4 & 533.2 & 1053.6 \\
\hline ASU Power (MWe) & 50.41 & 100.08 & 197.83 & 51.97 & 104.34 & 205.68 \\
\hline Other Aux. Power (MWe) & 12.7 & 24.7 & 47.8 & 12.2 & 24 & 46.5 \\
\hline Net Power (MWe) & $\mathbf{2 0 3 . 3}$ & $\mathbf{4 0 7 . 4}$ & $\mathbf{8 0 8}$ & $\mathbf{2 0 2 . 2}$ & $\mathbf{4 0 4 . 9}$ & $\mathbf{8 0 1 . 4}$ \\
\hline Net efficiency, HHV (\%) & $31.20 \%$ & $31.20 \%$ & $31.60 \%$ & $30.00 \%$ & $30.00 \%$ & $30.10 \%$ \\
\hline
\end{tabular}

Table 7: Overall process performances of the OEC plants

\section{TASK 4: CONCEPTUAL BOILER DESIGN}

As stated in "Experimental” section of last quarterly report (Q1 2004), the specification of this task as been modified and described in DOE/AL amendment. The task has been initiated with B\&W and some results will be provided in future quarterly reports. 


\section{PROJECT SCHEDULE}

The current status of the project tasks and sub-tasks is displayed below, followed by a short description of the work to be performed in the next quarter (July-Sep 2004).

\subsection{Status of the project tasks and sub-tasks}

The sub-tasks completed in previous reporting periods (bold \& black), completed in the current reporting period (bold \& blue), currently in progress or soon to be ongoing, are reported in Table 8 below.

Expected

Completion

$\underline{\text { Status }}$

\section{Task 1: Site Preparation}

Task 1.1: $\quad$ List of required modifications

Task 1.2: $\quad$ Conceptual design of SBS adaptations

Task 1.2: $\quad$ Technical design of SBS adaptations

Task 1.3: Implementation of SBS adaptations

Task 1.4: $\quad$ System shake-down
March 30, 2003 - Completed

April 15, 2003 - Completed

April 30, 2003 - Completed

July 30, 2003 - Completed

August 1, 2003 - Completed

\section{Task 2: Test Performance}

Task 2.1: $\quad$ Test matrix definition

Sept. 15, 2003 - Completed

Task 2.2: $\quad$ Tests performance

Heat Transfer and Mercury measurements

Task 2.3\&2.4: Test analysis \& Report

Dec. 15, 2003 - 13 days completed

June 30, 2004 - Completed

Sep 30, 2004 - In progress

\section{Task 3: Techno-Economic Study}

Task 3.1: $\quad$ Cases Specification

Task 3.2: $\quad$ Methodology Definition

Task 3.3: $\quad$ Process Simulation \& Cost Estimation

500MWe PC and oxy-boiler

500MWe PC calculation refinements

250 \& 500MWe IGCC

250MWe PC and oxy-boiler

1,000MWe PC and oxy-boiler

Task 3.4: $\quad$ Results analysis \& Report
Sept. 15, 2003 - Completed

Aug. 30, 2003 - Completed

Dec.31, 2003 - Completed.

Mar. 31, 2004 - Completed.

Mar. 31, 2004 - Completed.

June 30, 2004 - Completed

June 30, 2004 - Completed

June 30, 2004 - In progress

\section{Task 4: Preliminary Boiler Design}

Task 4.1: $\quad$ Task specification

Task 4.2: $\quad$ Design performance

Task 4.3: $\quad$ Results analysis \& Report
Mar. 30, 2004 - Completed

Sep. 30, 2004 - In progress

Dec. 31, 2004 - Future

Table 8: Project Schedule 


\subsection{Next quarters sub-tasks}

During the next quarter (July $1^{\text {st }}$ to September $30^{\text {th }}$ 2004), the following activities will be performed:

- The analytical chemistry of the mercury samples will be performed, and related data reduction and analysis completed.

- The experimental results gathered during the entire test campaign of this project will be analyzed and summarized.

- The report summarizing the work performed in the techno-economical study (task 3) will be completed. Conclusion regarding oxycombustion competitiveness vs air-blown system with amine scrubbing and vs IGCC will be reported.

- Preliminary results on engineering effort currently in progress in the boiler design task (task 4) will be reported.

\section{FINANCIAL STATUS}

Table 9 and Table 10 show the financial status of the report to-date. An amount of $\sim \$ 75 \mathrm{k}$ has been spent by the main contractor in the reporting period $\left(Q_{1}, 2004\right)$, including $\sim \$ 17 \mathrm{k}$ of direct labor, $\sim \$ 1 \mathrm{k}$ of travel, $\sim \$ 7 \mathrm{k}$ of material \& equipment related to oxygen, $\$ 28 \mathrm{k}$ of contractual and $\sim \$ 22 \mathrm{k}$ of indirect charges. To date, $\$ 945 \mathrm{k}$ have been spent and reported in the project. \$470k has been reimbursed by DOE-NETL.

\begin{tabular}{|c|c|c|c|c|c|c|}
\hline \multicolumn{3}{|c|}{ 10. Transactions: } & $\begin{array}{l}\text { I } \\
\text { Previously } \\
\text { Reported }\end{array}$ & \multicolumn{2}{|l|}{$\begin{array}{l}\text { II } \\
\text { This } \\
\text { Period }\end{array}$} & $\begin{array}{l}\text { III } \\
\text { Cumulative }\end{array}$ \\
\hline \multicolumn{3}{|c|}{ a. Total outlays } & $\$ 869,503.95$ & \multicolumn{2}{|c|}{$\$ 75,383.54$} & $\$ 944,887.49$ \\
\hline \multicolumn{3}{|c|}{ b. Recipient share of outlays } & $\$ 399,503.95$ & \multicolumn{2}{|c|}{$\$ 75,383.54$} & $\$ 474,887.49$ \\
\hline \multicolumn{3}{|c|}{ c. Federal share of outlays } & $\$ 470,000.00$ & & - & $\$ 470,000.00$ \\
\hline \multicolumn{3}{|c|}{ d. Total unliquidated obligations } & & & & - \\
\hline \multicolumn{3}{|c|}{ e. Recipient share of unliquidated obligations } & & & & - \\
\hline \multicolumn{3}{|c|}{ f. Federal share of unliquidated obligations } & & & & - \\
\hline \multicolumn{3}{|c|}{ g. Total Federal share (Sum of lines c and f) } & & & & \\
\hline \multicolumn{3}{|c|}{ h. Total Federal funds authorized for this funding period } & & & & $\$ 785,268.00$ \\
\hline \multicolumn{3}{|c|}{ i. Unobligated balance of Federal funds (Line h minus line g) } & & & & $\$ 315,268.00$ \\
\hline \multirow{2}{*}{$\begin{array}{r}\text { 11. Indirect } \\
\text { Expense }\end{array}$} & \multicolumn{6}{|c|}{ a. Type of Rate (Place "X" in appropriate box) } \\
\hline & $\begin{array}{l}\text { b. Rate } \\
\text { see attachment }\end{array}$ & \begin{tabular}{|l|l|} 
c. Base \\
see attachment
\end{tabular} & \multicolumn{2}{|c|}{$\begin{array}{l}\text { d. Total Amount } \\
\qquad \mathbf{2 2 5 , 2 1 1 . 9 5}\end{array}$} & \multicolumn{2}{|c|}{ e. Federal Share } \\
\hline
\end{tabular}

Table 9: Financial situation to-date. 


\begin{tabular}{|c|c|c|c|c|c|}
\hline Indirect Expenses & Rate & Base & & $\begin{array}{c}\text { Indirect expense } \\
\text { charged to the } \\
\text { project }\end{array}$ & $\begin{array}{c}\text { Federal share } \\
\text { for indirect } \\
\text { expense }\end{array}$ \\
\hline Labor Overhead & $87.94 \%$ & Total Direct Labor Costs & \$ 155,232.00 & $\$ 136,511.02$ & $\$ 0$ \\
\hline General \& Administrative & $10.36 \%$ & $\begin{array}{l}\text { Total Direct Project Costs } \\
\text { and Overhead Costs }\end{array}$ & \$ 856,186.56 & $\$ 88,700.93$ & $\$ 0$ \\
\hline \multicolumn{4}{|l|}{ Total Indirect Expenses } & $\$ 225,211.95$ & $\$ 0$ \\
\hline
\end{tabular}

Table 10: Indirect Expenses (details)

\section{OTHER ACHIEVEMENTS}

The project main results have been summarized in two papers and have been presented in Clearwater coal conference (April 2004) and $\mathrm{CO}_{2}$ sequestration conference (May 2004):

Sangras R., Châtel-Pélage F., Pranda P., Farzan, H., Vecci, S.J., Lu Y., Chen S., RostamAbadi M., Bose A.C., Oxycombustion process in pulverized coal-fired boilers: a promising technology for $\mathrm{CO}_{2}$ capture, The $29^{\text {th }}$ International Technical Conference on Coal Utilization \& Fuel Systems, Clearwater, FL, USA, 2004.

Varagani R., Châtel-Pélage F., Pranda P., Farzan H., Vecci S.J., Lu Y., Chen S., RostamAbadi M., Bose A.C., Oxycombustion in pulverized coal-fired boiler: a promising technology for $\mathrm{CO}_{2}$ capture, Third Annual Conference on Carbon Sequestration, Alexandria, VA, May 2-6, 2004. 


\section{CONCLUSION}

Significant progress have been made in the current reporting period on Task 2 (Experimental) Task 3 (economics) and Task 4 (boiler design).

Task 2 (Tests performance) has been completed. In addition to data collected in 2003 on oxy-fired boiler and on air-fired boiler, the heat transfer characteristics and mercury samples have been collected. Although these results are yet to be fully analyzed and discussed, the highlights are as follows:

- Burner stoichiometry, Flame stability and $\mathrm{NO}_{x}$ emission: to avoid getting a cooler and less stable flame in $\mathrm{O}_{2} / \mathrm{CO}_{2}$ conditions vs air-conditions, a same burner has to be operated at higher burner stoichiometry in oxy-configuration. This is due to higher molecular weight and heat capacity of $\mathrm{CO}_{2}$ vs $\mathrm{N}_{2}$. Increasing the burner stoichiometry in oxy-combustion is feasible without affecting $\mathrm{NO}_{\mathrm{x}}$ levels thanks to flue gas recirculation which keeps the $\mathrm{NO}_{\mathrm{x}}$ emission very low $\left(<0.1 \mathrm{lb} / 10^{6} \mathrm{Btu}\right)$ through the reburn mechanism.

- Emmissivity Measurement: The measured emissivity indicated that the flame emissivity under the oxy-combustion is similar to the flame emissivity under normal air firing conditions.

- Temperature Measurement: Temperature measurements were performed at the flame, furnace exit, and the convection pass outlet for both air firing and oxy-firing, while the overall mass flow rate was kept constant. The data are being analyzed. Pilot results seem to indicate that under those optimized conditions, the temperature profiles are similar in oxy-firing and in airfiring conditions (previous tests showed an average FEGT $70^{\circ} \mathrm{F}$ lower in oxy-firing).

- Mercury Measurement: Mercury sampling was performed at the convection pass outlet of SBS under normal air firing and oxy-combustion conditions, and the samples are currently being analyzed at Western Kentucky University.

The Techno-Economic Study (Task 3) has been completed in the current quarter. The oxycombustion process (OEC) using $99 \%$ purity of oxygen can achieve a $\mathrm{CO}_{2}$ level concentrated to about $93 \%$ in the gas stream. If a higher $\mathrm{CO}_{2}$ concentration is necessary, further gas separation and dehydration are required.

The auxiliary power use in the OEC process accounted for about $24 \%$ of the gross power output, resulting in a decrease of power generation efficiency to 30-32\%. The ASU contributed to $80 \%$ of the total auxiliary power usage.

Techno-economic analyses showed that compared to the new air-blown PC plant without $\mathrm{CO}_{2}$ capture, the cost of electricity (COE) of the OEC process increased by about 25-30\%, while that of the MEA-equipped air-blown PC plant increased by about $60 \%$ and that of the Selexolequipped IGCC plant increased by $20 \%$. The cost of the OEC process is slightly higher than the IGCC plant, but is more competitive than the MEA-equipped air-blown PC plant.

The OEC process and MEA process are technically applicable for plant retrofit to capture $\mathrm{CO}_{2}$ emissions. For a $533 \mathrm{MW}$ e power plant, the OEC retrofit required less than $\$ 300 / \mathrm{kW}_{\mathrm{e}}$ capital cost and increased 5 mills $/ \mathrm{kWh}$ O\&M cost. At the same plant size, the MEA retrofit required $\$ 460 / \mathrm{kW}_{\mathrm{e}}$ capital cost and $11 \mathrm{mills} / \mathrm{kWh}$ O\&M cost. The OEC process is economically favorable for the $\mathrm{CO}_{2}$ capture retrofit of the existing power plant. 
The Boiler Design Task (Task 4) had been initiated in the last quarter (Q1 2004). The scope of work (SOW) to be performed had been modified as per DOE request and the updated SOW had been reported. Engineering calculations are in progress and the corresponding results will be reported in further reports.

The project main results have been reported in two papers to be presented in conferences in April and May 2004.

The current work schedule is to perform analytical chemistry of the mercury samples, and to reduce and analyze the corresponding results. The experimental data collected during the entire 2003-2004 test campaign will be reviewed in details, analyzed and the main conclusions highlighted. The report summarizing the work performed in the Techno-Economic study (task 3) will be completed. Conclusion regarding oxycombustion competitiveness vs air-blown system with amine scrubbing and vs IGCC will be reported. Preliminary results on engineering effort currently in progress in the boiler design task (task 4) will be reported. 


\section{REFERENCES}

List of published reports that will be used for performing the techno-economic analyses (estimation of auxiliary powers and costs associated with various process areas):

\section{CONVENTIONAL PC POWER PLANT}

(1) Gilbert/Commonwealth Inc., Clean Coal Reference Plants: Pulverized Coal Boiler with Flue Gas Desulfurization, DE-AM21-94MC311 66, September 1995

(2) Office of Fossil Energy, US DOE, Market Based Advanced Coal Power Systems, DOE/FE-0400, May 1999

(3) United Engineers \& Constructors Inc, Total Generation Cost: Coal and nuclear Plants, DOE EY-76-C-02-2477, February 1979

(4) EIA, Electric plant cost and power production expenses 1988, DOE/EIA-0455, August 1990

(5) DOE/EIA , Steam-electric plant construction cost and annual production expenses, 1977

\section{$2 \quad \mathrm{CO}_{2}$ REMOVAL PROCESS}

(6) EPRI, Evaluation of Innovative Fossil Fuel Power Plants with $\mathrm{CO}_{2}$ Removal, Interim Report 1000316, December 2000

(7) EPRI, Updated Cost and Performance Estimates for Fossil Fuel Power Plants with $\mathrm{CO}_{2}$ Removal, Interim Report 10004483, December 2002

(8) Henrik Birkestad, Separation and Compression of $\mathrm{CO}_{2}$ in $\mathrm{O}_{2} / \mathrm{CO}_{2}$-Fired Power Plant, master thesis, Chalmers University of Technology, Sweden, 2002

(9) D. Singh, E. Croiset, P. L. Douglas and M. A. Douglas, Techno-economic study of $\mathrm{CO}_{2}$ Capture from an Existing Coal-Fired Power Plant: MEA Scrubbing vs. $\mathrm{O}_{2} / \mathrm{CO}_{2}$ Recycle Combustion, Energy Conversion and Management, 44(19), 2003: 3073-3091

(10) Edward S Rubin and Anand B Rao, A Technical, Economic and Environmental Assessment of Amine-based $\mathrm{CO}_{2}$ Capture Technology for Power Plant Greenhouse Gas Control, Annual Technical Process Report, DE-FC26-00NT40935, Oct. 2002

\section{FGD PROCESS}

(11) United Engineers and Constructions, Inc., Economic Evaluation of Flue Gas Desulfurization Systems, EPRI GS-7193, February 1991

(12) Srivastava R K, Controlling $\mathrm{SO}_{2}$ Emissions: A review of the Technologies, EPA/600/R00/093, November 2000 


\section{SCR PROCESS}

(13) Foerter D and Jozewicz W, Cost of Selective Catalytic Reduction (SCR) Application for $\mathrm{NO}_{\mathrm{x}}$ Control on Coal-fired Boilers, EPA/600/R-01/087, October 2001

\section{MERCURY REMOVAL PROCESS}

(14) US EPA, Mercury Study Report to Congress, Vol. VIII: An Evaluation of Mercury Control Technologies and Costs, EPA-452/R-97-010, December 1997

(15) U.S. EPA clean Air Markets Division, Documentation of EPA Modeling Applications (V.2.1) Using the Integrated Planning Model, EPA-68-D7-0081, March 2002

\section{IGCC PLANT}

(16) Scott Chen, Subhash Bhagwat, Massoud Rostam-Abadi, Techno-Economic Studies of Illinois Coal in Future Power production processes. ICCI Project No: 01-1/2.3C-1, October, 2002

(17) Destec Gasifier IGCC Based Cases, PED-IGCC-98-003, Prepared by EG\&G, Sept. 1998, revised June 2000.

(18) Economic Assessment of the Impact of Plant Size on Coal Gasification-Combined Cycle Plants, Prepared by Fluor Engineers, Inc. EPRI Report, AP-3084, May 1983.

(19) NETL of DOE, Destec gasifier IGCC Base cases, PED-IGCC-98-003, June 2000

(20) N. V. Akunuri, Modeling the Performance, Emissions, and Costs of Texaco GasifierBased Integrated Gasification Combined Cycle Systems, Master Thesis, North Carolina State University, 2000.

(21) IEA Greenhouse Gas R\&D Programmer, Potential for Improvement in Gasification Combined Cycle Power Generation with $\mathrm{CO}_{2}$ Capture, Report No.PH4/19, May 2003.

(22) Parsons Energy and Chemicals Group Inc, and Wolk Integrated Technical Services, Evaluation of Innovative Fossil Fuel Power Plants with $\mathrm{CO}_{2}$ removal, 1000316, DOE interim Report, Dec.2000

(23) Parsons Infrastructure \& Technology Group, Inc., Integrated Technical Services, Updated Cost and Performance Estimates for Fossil Fuel Power Plants with $\mathrm{CO}_{2}$ removal, 1004483, DOE interim Report, Dec.2002

\section{OTHERS}

(24) EG\&G Technical Services, Inc., ASPEN Plus Simulation of $\mathrm{CO}_{2}$ Recovery Process, DOE/NETL-2002/1182, Sep.2002 


\section{LIST OF ACRONYMS AND ABBREVIATIONS}

\begin{tabular}{|c|c|}
\hline AAL & American Air Liquide \\
\hline ACI & Activated Carbon Injection \\
\hline BSR & Burner Stoichiometric Ratio \\
\hline B\&W & Babcock and Wilcox \\
\hline $\mathrm{CHx}$ & Condensing Heat Exchanger \\
\hline CPEGT & Convective Pass Exit Gas Temperature \\
\hline $\mathrm{COE}$ & Cost of Electricity \\
\hline DOE & Department of Energy \\
\hline EPA & Environmental Energy Agency \\
\hline EPRI & Electric Power Research Institute \\
\hline ESP & Electrostatic Precipitator \\
\hline FD Fan & Forced Draft Fan \\
\hline FEGT & Furnace Exit Gas Temperature \\
\hline FG & Flue Gas \\
\hline FGD & Flue Gas Desulfurization \\
\hline FGR / RFG & Flue Gas Recirculation / Recycled flue gas \\
\hline FGT & Flame Gas Temperature \\
\hline $\mathrm{Hg}$ & Mercury \\
\hline HMI & Human Machine Interface \\
\hline HRSG & Heat Recovery Steam Generator \\
\hline ID Fan & Induced Draft Fan \\
\hline IGCC & Integrated Gasification Combined Cycle \\
\hline ISGS & Illinois State Geological Survey \\
\hline LOI & Lost On Ignition (same as UBC) \\
\hline LSD & Lime Spray Dryer \\
\hline MEA & Mono Ethanol-Amine \\
\hline NETL & National Energy Technology Laboratory \\
\hline OEC & Oxygen Enriched Combustion (Oxycombustion) \\
\hline O\&M & Operating And Maintenance \\
\hline PA & Primary Air \\
\hline PACI & Pulverized Activated Carbon Injection \\
\hline PC & Pulverized Coal (Boiler) \\
\hline PO & Primary Oxidant \\
\hline PRB & Powder River Basin \\
\hline SA & Secondary Air \\
\hline SBS & Small Boiler Simulator \\
\hline SCR & Selective Catalytic Reduction \\
\hline SNCR & Selective Non Catalytic Reduction \\
\hline SO & Secondary Oxidant \\
\hline TA & Tertiary Air \\
\hline
\end{tabular}


TBD To be defined

TCR Total Capital Requirement

TO Tertiary Oxidant

TPC Total Plant Cost

TPI Total Plant Investment

UBC Unburned Carbon in Ash (same as LOI) 